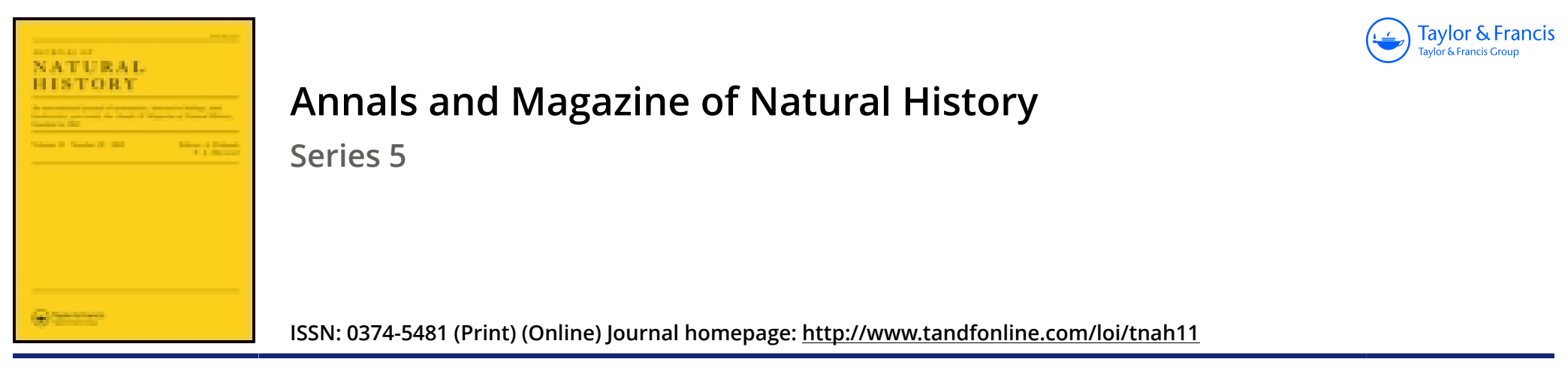

\title{
XIV. - on the geodephagous coleoptera collected by Mr. George Lewis in Ceylon
}

\section{H.W. Bates F.R.S.}

To cite this article: H.W. Bates F.R.S. (1886) XIV.- -on the geodephagous coleoptera collected by Mr. George Lewis in Ceylon, Annals and Magazine of Natural History, 17:98, 143-156, DOI: 10.1080/00222938609460124

To link to this article: http://dx.doi.org/10.1080/00222938609460124

\section{Published online: 07 Oct 2009.}

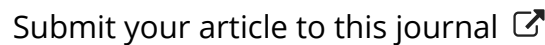

Џ Article views: 1 
XIV.-On the Geodephagous Coleoptera collected by Mr. George Lewis in Ceylon. By H. W. Bates, F.R.S.

[Continued from p. 81.]

Subfamily PTEROSTICHIN.s.

Morio Walkeri.

Morio Walkeri, Putzeys, Ann. Mus. Civ. di Storia Nat. di Genova, iv. p. 216.

Kandy.

Morio trogositoides, Walker (Ann. \& Mag. Nat. Hist. 1858,

ii.), according to the type is very similar to $M$. Walker $i$ in general form, but differs in the front edge of the thorax being triangularly excised in the middle, as in $1 \%$. orientalis, from which it differs in the frontal fovea not being dilated behind.

Morio cordicollis.

Morio cordicollis, Chaudoir, Bull. Mosc. 1880 , Ess. Monogr. 8. 1. Morionides, p. 27.

Kandy and Balangoda.

Diceromerus orientalis.

Diceromerus orientalis, Motschulsky, Etud. Ent. 1859, p. 35 (Stomonaxus orientalis); Chaudoir, Liss. Monogr. s. I. Drimostomides et les Cratocérides, p. 15.

Dikoya, conmon in refuse.

\section{Abacetus atratus.}

Abacetus atratus, Dej. Sp. Gén. iii. p. 194; Chaudoir, Essai Monogr. s. 1. Gen. Abacetus, p. 3 (Bull. Mosc. 1875),=Distrigus costatus, Nietner, Ann. \& Mag. Nat. Hist. 1858, ii. p. 176.

Colombo.

Abacetus quadriguttatus.

Abacetus qualriguttatus, Chaudoir, Essai Monogr. s. 1. Gen. Abacetus; p. 33 ?

Kandy, sandy river beds.

Chandoir's specimens were from Burma. The Ceylonese insect does not in all points correspond with his description; but it does so sufficiently to show that, if it be not the same species, it is only a slight modification. 


\section{Abacetus lioderes.}

Gracilis, facies Anchomeni, nigro-piceus, supra ænescens ; antennis articulo primo sanguineo, palpis tarsisque fulro-testaceis, femoribus tibiisque obscure rufo-testaceis; sulcis frontalibus brevibus versus oculum curratis ibique profundioribus: thorace angusto, postice gradatim sinuato-angustato, angulis posticis exstantibus, basi lævi; elytris profunde usque ad apicem striatis, striis lævissimis.

Long. $5 \frac{1}{2}$ millim.

Colornbo.

Peculiar in this genus for its Anchomenus-like form, the thorax especially being more narrowly cordate than in other species, having its greatest width at the anterior third, and thence gradually and considerably narrowing to the base, before which the sides are briefly and strongly sinuated, causing the hind angles to project, though the base runs obliquely up on each side towards the angle. The base of the thorax has no trace of punctuation, the dorsal line does not deepen near the base, and the space between the straight and deep basal sulci and the margin is narrow and triangular. The arcuated anterior transverse suleus is rather strongly marked; the lateral margins are explanate-reflexed. The elytral striæ have no trace of punctures.

\section{Abacetus carinifrons.}

Supra totus læte æneus, subtus castaneo-niger, sulcis frontalibus rectis usque ad oculorum margines posticos extensis et extus carina recta marginatis; thorace late quadrato-cordato, basi sat constrieto, angulis posticis rectis, inter sulculos basales grosse punctato; elstris striatis, interstitiis plauis ; antennis pedibusque piceis vel rufescentibus, illis articulis $1-2$ rufis.

Long. $5 \frac{1}{2}$ millim.

Colombo, in marshes.

Belongs to Chaudoir's section iv. 1. b, with the difference that the basal joint of the posterior tarsi is faintly sulcate on the outer side. The third antennal joint is certainly glabrous and not pilose, except the usual two or three bristles at the end.

\section{Abacetus antiquus.}

Abacetus antiquus, Dejean, Sp. Gén. iii. p. 246 (Feronia); Chaudoir, Essai Monogr. Abacetus, p. 37.

Distrigus submetallicus, Nietner, Ann. \& Mag. Nat. Hist. 1858, ii. p. 177 .

Argutor relinquens, Walker, Amm. \& Mag. Nat. Hist. 1858, ii. p. 204.

Colombo. 


\section{Abacetus anomalus.}

Abacetus anomalus, Chaudoir, Essai Monogr. Abacetus, p. 13.

Colombo.

\section{Abacetus Nietneri.}

Abacetus Nietneri, Chandoir, Essai Monogr. Abacetus, p. 38.

Distrigus eneus, Nietner, Ann. \& Mag. Nat. IIist. 1858, ii. p. 177 (nom. præocc.).

Colombo.

\section{Trigonotoma indica.}

Trigonotoma indica, Brullé, Hist. Nat. des Ins. iv. p. 333.

Colombo.

\section{Lagarus (?) impunctatus.}

Oblongus, niger, politus, elytris subviridescentibus ; palpis, antennis et tarsis piceo-rufis; oculis convexis ; thorace impunctato, quadrato, lateribus fere rectis, basi utrinque sulco profundo abbreviato, recto; elytris thorace vix latioribus, parallelis, striis lævibus novem profundis et acute insculptis, ostaro et nono antice approximatis, striola scutellari nulla, interstitiis subconvexis, tertio impunctato: metasterno ventrisque basi lateribus punctulatis.

Long. 10 millim. 오.

Colombo, in marshes.

In its generic characters this Harpalus-like Pterostichusform approaches Layarus and Omaseus, the form of the metathoracic episterna being nearly the same as in Omaseus niger; but it differs from those and all other genera or subgenera of Pterostichinæ known to me by a combination of minor characters. The mentum is deeply emarginated and its central tooth is broad and deeply concave without being distinctly bifid; the palpi are rather slender, with cylindrical and truncated apical joints; the antennæe are rather long and filiform, and the second joint articulated to the middle apex of the scape; the head narrowed behind the prominent eyes, with fine and strongly curved frontal furrows; the thorax is quadrate, rather broader than long, with a deep sulcus similar to that of the Abaceti, but distant from the base; the elytra are equally and strongly striated, without scutellar striole or puncture on the third interstice; the prosternum is strongly margined at the apex, as in Lagarus; the ventral segments are without transverse furrows, the posterior tarsi slender and free from sulci. Two examples taken by Mr. Lewis, both females; hence the form of the dilated anterior tarsi of male is unknown. 


\section{Subfamily ANCHOMENINE.}

\section{Anchomenus illocatus.}

A. micanti (Nicol.) primo intuitu similis, sed pedibus flavis ete. valde differt. A. alpino (Motsch.) magis affinis. Gracilis, piceoniger, supra ænescens, pedibus melleo-tlavis, palpis et articulis 1-3 antennarum flavis plus minusve fusco-maculatis; thorace parro, subcordato, ante medium subangulatim leviter dilatato, deinde ad basin subrecte angustato, angulis anticis rectis, posticis rotundatis, margine laterali anguste explanato-reflexo, versus basin altiori, foveaque utrinque basali lata profunde rugulosa; elytris acute punctulato-striatis, interstitiis planis, tertio tripunctato; tarsis 4 posticis utrinque sulcatis.

Long. $5 \frac{1}{2}-7$ millim. of $q$.

Nuwara Eliya ; shores of the lake.

Distinguished from the allied species by the yellow colour of the legs; the trochanters, four anterior coxr, and tips of the hindmost coxæ are also yellow. In the Siberian $A$. alpinus, which has similarly punctured stria, but which is larger and more robust, the tibire only are tawny testaceous. $C$. dolens (Sahlb.) and C. charillus (Bates) are similar to $A$. illocatus in general form and colour, but have a differently shaped, i. e. more quadrate, thorax. Argutor degener and Anchomenus illocatus, Walker (Ann. \& Mag. Nat. Hist. 1858, ii. pp. 203, 204), both belong to this species.

\section{Anchomenus ceylonicus.}

Anchomenus ceylonicus, Motschulsky, Etud. Ent. 1859, p. $\ddot{86 .}$

Dikoya; beaten from old branches.

Motschulsky's description is unusually good. It is necessary only to add that the species is closely allied to the N.W. American A. obsoletus, Say.

\section{Colpodes xenos.}

C. mutatori affinis, at quoad formam C.carcliophoro haud dissimilis; elytris sicut in hoc convexis, elongato-ovatis. Piceo-niger, nitidus, palpis et antennis fulvo-piceis, pedibus paullo obscurioribus; capito post oculos gradatim angustato ; thorace elongato-cordato, lateribus postice longe sinuatis, angulis posticis rectis (apice obtusis), marginibus sat late explanato-reflexis ; elytris convexis, elongatoovatis, basi angustis, apice singulatim acuminatis, acute et sat profunde striatis, interstitiis planis tertio tripunctato.

Long. 9 millim.

Bogawantalawa, April 1st.

Belongs to Division I. of Chaudoir's monograph, 1878. The fourth tarsal joint in all the fect is bilobed, with the exte- 
rior lobe in the four hinder feet the longer; the middle tarsi are grooved on each side, the lind tarsi on the outer side only; beneath, all four have a scanty, stiff, and short pubescence. The thorax is relatively long and very similar in outline to that of the New-Zealand $C$. cardiophorus, but the lateral margins are more reflexed, especially near the hind angles, than they are in that species, and the surface is smooth and glossy. The lateral margins of the elongate-oval convex elytra are also, especially in the middle, explanate-reflexed, the junction at the shoulder with the strongly curved and short basal margin forms an acute angle; the apex of the elytra is very obliquely sinuate truncate, and each elytron tapers to a short point near the suture; all the stria are equally strongly impressed.

One example only.

$$
\text { Colpodes amonus, Chaudoir. }
$$

Colprodes amoenus, Chandoir, Ann. Soc. Ent. Fr. 1859, p. 326, $=C$. splendens, Morawitz, Bull. Ac. Petrop. v. 1863, p. 324.

Dikoya.

'This fine species has a wide distribution. I have examined examples from N.W. India, Java, and Japan.

\section{Colpodes lampriodes.}

C. ruficipiti (Macleay) similis, sed differt pedibus rufo-testaceis, immaculatis, elytrisque margine apicali oblique flexuoso, apud suturam solum spinoso.

Long. 8 millim.

Hadley and Dikoya; under garden refuse.

Judging from the few words of description this appears to be the species erroneously referred by Chaudoir to the Euplynes Dohrni of Nietner, which is similar in shape and colouns, but generically different in the fourth tarsal joints having two long equal lobes, and is unmistakably described by Nietner. Chaudoir had examined a "type provenant de Nietner ;" it appears therefore that the original describer of the species confounded the similarly coloured Colpodes with his Euplynes. Chaudoir himself had apparently never seen a Luplynes, as he referred Schmidt-Göbel's Euplynes cyanipennis in both his monographs (1859 and 1879) to Colpodes ruficeps, Macl. With regard to Macleay's species, I think that Chaudoir also made a mistake, but this arose from Macleay's unsatisfactory description. C. ruficeps appears to be peculiar to Java and Sumatra*, and to differ front the nume-

* An example taken by Dr. Beccari on Mount Singalang was kindly comnunicated to me by Inr. Gestro of the Huseo Civico of Genoa, together with a specimen of $C$. smaragdinipennis (Chand.) from the same locality. 
rous allied species in the elytra being transversely truncated near the suture and being there bispinose, $i . e$. there is a short spine at the sutural and at the external end of the truncature. In C. lampriodes there is no sutural truncature, the apical margin being oblique and slightly flexuous from the sutural spine.

The basal margin of the elytra in C. lampriodes is red, the deflexed lateral margin purplish black; the surface of the elytra in all the numerous examples is of a beantiful dark blue, the rest of the insect immaculate testaceous red.

Lebia bipars, Walker (Ann. \& Mag. Nat. Hist. 1858, ii. p. 203), is a Colpodes very similar in form to the present; the black elytra, as described by the author, appear to be the result of discoloration, although the surface in the type specimen is glossy and appears clean. Walker's specific name, I think, should not in any case be adopted, as it is impossible to identify the species from his erroneous description.

\section{Colpodes retusus.}

Piceo-niger ; antennis, palpis, thoracis margine pedibusque dilutioribus; eapite mox pone oculos magnos angustato; thorace relatjve parro, quadrato, antice leviter rotundato-dilatato, postice paullo sinuato-angustato, angulis posticis rectis, margine laterali explanato-reflexo ; elytris sat late oblongis, apice oblique sinuatis inermibus, dorso utrinque ante medium depresso punctulato-striato, interstitiis planis, tertio tripunctato.

long. 8-11 lin.

Kandy.

Belongs to the group of Chaudoir's Division III. in which the four hinder tarsi are bisulcate with the space between the sulci carinate, the fourth joint unilobular, and the sutural apex of the elytra unarmed. The two anterior tarsi have only a very faint trace of sulci; the four hinder tarsi are slender.

\section{Colpodes repletus.}

C. lampros proxime affinis, differt thorace multo latiore. Rufotestacens; capite thoracisque disco castuneo-nigris ; elytris (margine excepto) olivacco-aneis ; capite parro, orato, post oculos angustato; thorace transverso, lateribus arenatis et late explanato-reflexis, angulis posticis obtusis, subrotundatis, basi utrinque profunde concaro, lævi; elytris apice ad suturam inermibus, extus sinuatis, dorso subpunctulato-striatis, interstitiis subplanis, tertio tripunctito.

Long. 8 millin.

Bogawantalawa.

Closely allied to the Japanese (!. lampros, from which it 
differs in the much broader thorax with sides more regularly arcuated, so that it is not narrower behind than in front, and by the duller and less golden-bronze colour of the elytra. All six tarsi have a fine sulcus on each side, and the fourth joint of the posterior pair is lobed on its outer side. The first elytral puncture is near the third stria, the second and third near the second stria.

\section{Colpodes iteratus.}

C. speculatori (Harold) affinis, differt tantum thorace angusto margine angustius explanato-reflexo et ante angulos posticos (valde obtusos) sinuato. Gracilis, rufo-testaceus, abdomine piceo, capite thoracisque disco nigris, nitidis; elytris olivacco-æneis, margine testaceo : capite parvo mox post oculos citius angustato, oculis prominulis; thorace anguste ovato rel leviter cordato; elytris angnste oblongis, postice paullo latioribus, apice inermibus leviter sinuatis, subpunctulato-striatis.

Iong. 6-8 millim.

Dikoya and Nuwara Eliya, in wet places.

Belongs with C. speculator (Har.), japonicus (Motsch.), and aurelius (Bates) to a group of Chaudoir's Division III., distinguished by the hindmost tarsi having no groove on the inner side and their fourth joint being simply emarginated, not unilobular. In their colours they all resemble $C$. lampros, C. modestior, C. sylphis, and others, in which the same tarsi have a fine groove on each side (not visible viewed from above) and a unilobular fourth joint.

Subfamily PERIGonines.

Perigona nigrifrons.

Nestra nigrifrons, Motschulsky, Etud. Ent. 1859, p. 38.

Bogawantalawa.

\section{Perigona ruficollis.}

Perigona ruficollis, Motschulsky, Bull. Mosc. 1851, iv. p. 506 (Nestra ruficollis); Putzeys, Ann. Mus. Civ. Genova, iv. p. 222.

Kandy.

The three dorsal setiferous punctures of the elytra in the examples which I refer to $P$. ruficollis, and which agree precisely in the described colours, are very conspicuous, and the third placed close to the apex. It varies in length from 3 to $3 \frac{1}{2}$ millim.

\section{Perigona sinuaticollis.}

P. ruficolli similis, sed differt thoracis lateribus postice valde sinuatis, angulis posticis rectis; rufo-testacea, capite nigro, elytris plaga 
utrinque discoidali fusca (haud nigra) indistincte delimitata, vitta testacea, suturali, post medium dilatata, versus suturam late striatis, striis punctulatis sed paullo et vage impressis, punetis 3 dorsalibus setiferis vix perspicuis, tertio sat longe ab apice (sed haud valde distanti sicut in $P$. nigrifronte) apud interstitium tertium, secundo vero in stria secunda.

Long. $3 \frac{1}{2}-4$ millim.

Dikoya.

Very similar to P.ruficollis in its general form, red-testaceous colour, and black head, but decidedly distinct in the longer and posteriorly sinuated thorax, in the lighter brown and less definite central portion of the elytra, and other characters.

Perigona fimicola.

Trechus,fimicola, Wollaston, Ins. Maderens. p. 63; id. Col. Hesperid. p. 27 (Trechichus).

Colombo.

According to three specimens I have examined of this species, taken at the Cape-Verd Islands and named by Wollaston, the apex of the elytra is broadly black, the elytra have a silky subopalescent gloss, three (and not two as stated by Wollastor's original description) conspicuous dorsal setiferous punctures, the third very distant from the apex, and a faint dusky cloud or large oblong spot common to both elytra extending from the base to three fourths of their length. Mr. Lewis's specimens agree exactly in all these points and in structural characters with Wollaston's insect. The species seems to me also scarcely different from the North-American P. nigriceps, Dej. I should include also Spathinus nigriceps, Nietn., which is a Perigona or very nearly allied to it, if the author had not stated that the labrum is deeply emarginated, which it is not in P. fimicola.

\section{Perigona Beccarii.}

Perigona Beccarii, Putzeys, Ann. Mus. Cir. Genova, vii. p. 732 ?

Dikoya ; abundant in refuse.

The insect referred to this species differs from $P$. fimicola only in colours, the large dorsal spot being darker and better defined against the lighter testaceous ground-colour of the elytra, which forms a submarginal vitta on each'side, curving to the suture behind, between the dorsal spot and the black apex. 'This agrees with Putzeys' description of the Bornean P. Beccarii. On comparing a large number of examples I find, however, that the elytra of $P$. Beccarii are always smoother and glossier, the striæ still more feebly impressed or entirely invisible; the thorax, too, has rather straighter sides and more 
distinct though obtuse hind angles, in some examples preceded by a slight sinuosity. In P. fimicola the sides fall obliquely to the obtuse hind angle.

Putzeys' description of the basal fold of the elytra is quite applicable to the Ceylonese specimens; but many of the other details given by him seem to me fanciful or inaccuratethat is, supposing the species are really the same. The following is evidently a colour variety :-

\section{Var. Perigona suffusa.}

Caput nigrum, thorax castaneo-rufus ; elytra toto castaneo-fusea (apice nigra), vitta utrinque submarginali a basi usque propo apicem ibique intus currata, pallide testacea.

The difference from the type form consists in the darker thorax and the extension of the large common spot of the elytra to the apex. It approaches very near $P$. tachyoüdes, Bates, which is, however, snfficiently distinct in the more tawny hue of the light parts and the more convex elytra.

\section{Subfamily BIMrDIDINA.}

\section{Tachyta umbrosa.}

Tachyta umbrosa, Motschulsky, Etud. Ent. 1862, p. 32,=Acupalpus extremus, Walker, Ann. \& Mag. Nat. Hist. 1858, ii. p. 204 ?

Dikoya.

Very similar to the widely distributed $T$. nana, from which it differs only in the more strongly marked and punctulated elytral strix, the posterior dorsal setiferous puncture situated in the fourtl (instead of the third) stria, and in the lighter tawny testaceous antennæ. Several specimens agreeing with one from Kiu-Kiang on the Yang-tsze. It is probably the Acupalpus extremus, Walker, but only a fragment of Walker's type in the British Museum remains for comparison.

\section{\$1. TACHYs proprie dictus. Tachys tropicus.}

Bembidium tropicum, Nietner, Ann. \& Mag. Nat. Hist. 1858, ii. p. 421. Dikoya.

\section{Tachys triangularis.}

Bembidium triangulare, Nietner, Ann. \& Mag. Nat. Hist. 1858, ii. p. 422. Dikoya and Colombo.

\section{Tachys subvittatus.}

T. tropico et T. triangulari affinis, sed differt striis prope suturam utrinque 4 rulto minus impressis, magis abbreviatis et inconspicue 
punctulatis, punctoque dorsali anteriori extus nltra striam quartam sito: major, rufo-testaceus, elytris dorso depresso plaga elongato-ovata, suturali (a basi usque ultra medium) margine(jue laterali aneo-fuscis sericeis suffusis; thorace angulis posticis ralde exstantibus, sulco basali lævi sed margine basali longitudinaliter striguloso.

I.ong. $3 \frac{1}{1}$ millim.

\section{Dikoya.}

Very much larger than T. triangularis and differently coloured. Approaches much nearer T. tropicus, from which it differs chietly in the feebler stria and the situation of the anterior setiferous puncture, which is quite outside the fourth stria, on the smooth part of the elytron, and not in the fourth interstice as expressly stated by Nietner of $T$. tropicus, and as shown in the Ceylonese specimens referred to that species.

\section{Tacliys spilotus.}

T. bistriato afinis, sed multo major elytrisque flavo-guttatis etc. Elongato-oblongo-ovatus, subdepressus, castaneo-niger subopalescenti-nitens ; antennis fuscis, articulis $1-3$, palpis, pedibus elytrisque utrinque guttis parum distinctis duabus (prima subhumerali, secunda transversa ante apicem) flavo-testaceis ; sulcis frontalibus brevibus, latis; thorace transversim quadrato, postice mediocriter angustato, angulis posticis rectis, margine basali, pedunculo et scutello testaceis; elytris ntrinque striis 3 haud acute incisis, puncto dorsali in stria tertia sito.

Long. $2 \frac{2}{3}$ millim.

Colombo.

Closely allied to the European $T$. bistriatus, but much larger, and the elytra more glossy and with slight opalescent reflections; the thorax is much broader and is differently formed near the hind angles, these being rectangular or eren acute, and the hind margin from the angle to the slight median lobe being much less oblique. The single dorsal puncture is in the middle of the elytra; the second puncture, as in all the species of this section, lies within the apex of the recurrent striole.

\section{Tachys atomarius.}

Tachys atomarius, Wollaston, Col. Hesperidum, p. 28,=Polyderis tenella, Motsch. Etud. Ent. 1862, p. 35 ?

Bogawantalawa.

One example, exactly agreeing with a specimen named by Wollaston from the Cape-Verd Islands. The recurved striole is wanting, or, what seems more likely, removed nearer to the 
lateral apical margin; the usual setiferous puncture exists, however, near its normal position in the typical group of the genus, $i$. e. where the curved apex of the recurved striole should be.

Tachyta microscopica, Bates, from Japan, agrees in all essential points of structure with T. atomarius, and is scarcely more than a geographical variety of the same. T. livida, Bates, an Australian species, is a more distinct species of the same group.

5 2. Subgen. Banytachys (Chaudoir).

T'achys bioculatus.

Taclys bioculatus, Putzeys, Ann. Mus. Civ. Genova, 1875, p. 743.

Abundant everywhere.

\section{Tachys eueides.}

Gracile ovatus, convexus, ænescenti-niger ; elytris ntrinque maculis rotundatis duabus rufis, altera subbumerali (interdum indistincta vel obsoleta), altera subapicali ; antennis gracillimis, palpis pedibusque testaceo-flavis; fronte sulco utrinque angulato profundo et extus prope oculam foveola rotundata; thorace relative parvo, antice rotundato, prope basin constricto angulisque acutis ; elytris striis utrinque prope suturam acutis impunctatisque.

Long. 3 millim.

Dikoya, abundant.

Differs from $T$. bioculatus and allies by the relatively small and narrow thorax, the basal furrow of which is crenulated and interrupted in the middle, as in the allied species. In all the numerous examples the antennæ and palpi as well as the legs are of a clear honey-yellow colour. The antennæ are long and slender and the joints two to five are nearly equal in length. There is no trace of a third elytral stria, and the two discoidal punctures are very conspicuous.

\section{Tachys peryphinus.}

Paullo magis oblongus et minus convexus, ænescenti-niger; elytris utrinque maculis duabus (vix distinctis et interdum obsoletis), altera subhumerali alteraque subapicali, rufis; antennis palpisque articulo penultimo nigro-fuscis, illis articulis $1-3$, his basi pedibusque melleo-flavis ; fronte utrinque sulcis brevibus duobus; thorace sat late rotundato-cordato, basi sinuato-angustato, angulis posticis acutis : elytris utrinque striis 1-2 profunde insculptis et punctulatis, striisque tertia et quarta certo situ conspicuis, punctis duobus dorsalibus in stria tertia sitis.

Long. 3 millim.

Kitngalle, on the river-side.

In form of body similar to $T$. Lucasi (Duval), but the Ann. \& Mag. N. Hist. Ser. 5. Vol. xvii. 
thorax is a little longer and less transverse than in that species, and the third stria is not so sharply incised. The general colour is pitchy black or dark castaneous with a strong brassy tinge. 'The basal sulcus of the thorax is faintly crenulated as in the allied East-Asiatic species, and interrupted in the middle, where the deeply impressed termination of the dorsal line forms a distinct fovea. The red spots of the elytra are not sharply defined on their borders and cannot be called "round;" they are sometimes very small or disappear altogether.

\section{Tachys ornatus.}

Bembidium ornatum, Nietner, Ann. \& Mag. Nat. Hist. 1858, ii. p. 426.

Kandy.

Specimens taken by Mr. Lewis agree with Nietner's description, except that the yellow elytral spots are not "orbicular," but (especially the posterior one) transverse. The forehead has two short parallel furrows on each side, and the elytra have no trace of striæ between the second (from the snture) and the eighth.

Putzeys's redescription (Ann. Mus. Civ. Genova, 1875, p. 21), in which he says "antennarum basi testaceis," cannot apply to Nietner's B. ornatum, which has uniformly pale antennæ and palpi.

T. pocilopterus (Bates), from $\mathrm{Fu}$-chau, is closely allied to $T$. ornatus and $T$. scydmonoüdes, but it is rather larger and sufficiently distinct from both in the form of the thorax.

\section{Tachys scydmcenoïdes.}

Bembidium scydmanoides, Nietner, Ann. \& Mag. Nat. Hist. 1858, ii. p. 427.

Colombo.

The sides of the thorax are sinuate-angustate from the middle to the basal angles (making the base "fortius quadrato," as Nietner expresses it), the frontal furrows are broad and deep, and the antennal joints from the fourth more or less dusky.

The size is, as in T. ornatus, 2 millim.

\section{Tachys infans.}

Parvus, oblongo-ovatus, mediocriter convexus, pallide testaceus; elytris medio vitta lata pallide fuscescenti; fronte utrinque suleo brevi unico; thorace transverso, antice late rotundato, versus basin valde angustato, angulis posticis acutis; elytris utrinque striis punctulatis tribus, punctis 2 dorsalibus in stria tertia sitis.

Long. 2 millim.

Kandy. 
Differs from other small pallid Tachydes in its more oblong and less convex form of body and the smaller thorax strongly narrowed towards the base. The elytra are flattened on the dorsal surface and the three punctured strix on each side of the suture are somewhat sharply impressed with a very faint and short rudiment of a fourth stria. There are two strongly impressed marginal striæ on each side.

\section{Tachys amplians.}

T. globulo (Dej.) proxime affinis et simillimus; differt solum colore pallide testaceo striisque paullo distinctius punctulatis vel crenatis. Brevis, convexus, flaro-testaceus, antennis (articulis 1-2 exceptis) fuscescentibus; thorace valde transverso, lateribus versus basin sinuatis, angulis posticis subacutis; elytris stria suturali integra striisque 2-4 valde abbreviatis, parum incisis, erenulatis, stria marginali unica, puneto dorsali anteriore deficiente.

Long. 2 millim.

Kandy.

The elytra appear a little longer and more pointed at apex than in T. globulus. To this small group of Tachys, distinguished by the disappearance of the submarginal stria (the eighth), of which a few large punctures at the base and apex only remain, belongs also $T$. perlutus (Bates).

\section{Tachys emarginatus.}

Bembidium emarginatum, Nietner, Ann. \& Mag. Nat. Hist. 1858, ii. p. 425 .

Colombo.

Putzeys's description (Ann. Mus. Civ. Genova, 1875, p. 739) does not agree with Nietner's, nor with the numerous specimens taken by Mr. Lewis, as he gives the size as $1 \frac{1}{4}$ millim. and states that the elytra have four red spots. The size is 2 millim. or a little longer ( 1 line, Nietner), and the elytra have only two subapical spots. The colour varies from pale testaceous, through castaneous, to bright pitchy black with an æneous tinge.

The species occurs in China (at Fu-chan and on the lower Yang-tsze Kiang) as a pale variety, exactly similar to the pale Ceylonese form, except that the lighter subapical spots are not quite so well defined; this is the insect alluded to as T. scydmenoüdes, Nietn., in Geod. Col. Japan, Trans. Ent. Soc. 1873, p. 299.

\section{Tachys Klugii.}

Bembidium Klugii, Nietner, Ann. \& Mag. Nat. Hist. 1858, ii. p. 423.

Colombo. 


\section{Tachys orientalis.}

Bembidium orientale, Nietner, Ann. \& Mag. Nat. Hist. 1858, ii. p. 425.

Colombo.

\section{Tachys notaphoüdes.}

Flongato-oblongo-ovatus, subdepressus, castaneo-fuscus vel rufus, ænescens; elytris utrinque maculis duabus transversis, pedibus antennarumque articulo primo (cæeteris nigro-fuscis) flavo-testaceis ; fronte utrinque bistriato; thorace quadrato, ante medium vix rotundato, postice parum angustato, angulis posticis rectis vel subacutis, margineque basali fere recto medio sinuato; elytris 9 -striatis, septima fere obliterata, secunda ad sextam apice abbreviatis, octava et nona parallelis approximatis; punctis 2 dorsalibus apud interstitium tertium sitis.

Long. $2 \frac{1}{2}$ millim.

Kitugalle, on the river-side.

Unlike any other species known to me. The elytral stria are finely and sharply incised, the sixth being rather less deep and the seventh faint but distinct, the eighth runs throughout parallel to the ninth or marginal. The recurved striole is very deeply impressed, long and regularly curved. In these respects it differs from $T$. orientalis and $K$ Klugii, in which the eighth stria is much curved and recedes from the ninth in its middle course and the recurved striole is very short.

\section{Bembidium europs.}

B. nilotico proxime affinis, differt solum tegumento subtilissime alutaceo, subopaco, striisque frontalibus parum impressis, interruptis.

Long. $3 \frac{2}{3}$ millim.

Kandy.

From B. niloticum, which has a wide range from Egypt to China and New Caledonia, and presents only tritling local modifications, the single example taken by Mr. Lewis differs in its finely shagreened surface, similar to that of many species of Bracteon. To this are added the much fainter frontal furrows, which, instead of being deep sulci, running (and diverging) from the epistome to the hind margin of the eyes, are faint and interrupted, and the space between them shows no convexity. The general colour is lighter brassy, and the testaceous spot at the apex of the elytra, instead of forming a large lunule on each side, is broken up into tesselated spots.

[To be continued.] 